\title{
Spatial Variability Mapping of Available Nutrient Status in Vegetable Grown Soils Using GIS Techniques
}

\author{
D. Muthumanickam* \\ Horticultural College and Research Institute, Periyakulam, Theni, \\ Tamil Nadu, 625601, India \\ *Corresponding author
}

\begin{tabular}{l} 
K e y w o r d s \\
$\begin{array}{l}\text { Soil fertility, Spatial } \\
\text { variability, Site } \\
\text { specific nutrient } \\
\text { management }\end{array}$ \\
\hline Article Info \\
\hline $\begin{array}{l}\text { Accepted: } \\
\text { 26 April } 2020 \\
\text { Available Online: } \\
\text { 10 May } 2020\end{array}$ \\
\hline
\end{tabular}

\section{Keywords}

Soil fertility, Spatial variability, Site specific nutrient management

Article Info

Accepted:

Available Online:

10 May 2020
A B S T R A C T

Knowledge of spatial variability in soil fertility is important for site specific nutrient management. In this study, spatial variability in properties that influence soil fertility such as soil organic carbon, free $\mathrm{CaCO}_{3}$, available macro and micronutrients in surface soils of western farm of Horticultural college and Research Institute (HC\&RI), Periyakulam taluk of Theni district of TamilNadu were quantified and respective thematic maps were prepared on the basis nutrient rating using Arc Map 10by employing interpolation method. Soils were slightly alkaline in reaction with normal electrical conductivity. The coefficient of variation values for soil $\mathrm{OC}$, available $\mathrm{B}$ and available $\mathrm{Zn}$ were $0.43,0.74$ and 0.55 respectively. Organic carbon content in the soils was low in majority of the samples. Among the major nutrients, available $\mathrm{N}$ become most limiting nutrient (91.3\% deficient) while in micronutrients, $\mathrm{Cu}$ is deficient in $98.4 \%$ of samples As per the nutrient index value, fertility class of soil samples are very low, marginal and adequate respectively for available $\mathrm{N}, \mathrm{P}$ and $\mathrm{K}$ while very high, adequate, low, very low and marginal for DTPA extractable $\mathrm{Fe}, \mathrm{Mn}, \mathrm{Zn} \mathrm{Cu}$ and HWSB respectively. The observed spatial variability in various soil properties that influence soil fertility will be helpful for making crop management decisions.

\section{Introduction}

Indian agriculture during the past 50 years has achieved a fourfold growth in food production by adopting modern agricultural practices. However, intensive cultivation of higher yielding varieties, decreased use of organic manures and lack of crop residue recycling have led to depletion of native nutrient fertility and resulted in wide spread nutrient deficiencies. The extent of nutrient deficiency varies not only in different fields but also differ with in fields. The soil nutrients are essential for crop growth and development, and their content in soil depends on parent material, pedogenic processes and soil management (Sood et al., 2009).

The spatial variability of soil nutrient promotes, rational management of soil for 
agricultural sustainability. Describing the spatial variability across a field has become difficult until new technologies viz., Global Positioning System (GPS) and Geographic Information System (GIS) were introduced. GIS is a powerful set of tools for collecting, storing, retrieving, transforming and displaying spatial data. GIS used in producing soil fertility map of an area useful for understanding soil fertility status by spatially and temporally, further assist for formulating site-specific balanced fertilizer. By this technology, fields are accurately mapped and complex spatial relationship between soil fertility factors are computed (Patil et al., 2011). Spatial variability achieved through the analysis of spatial covariance or semivariogram interpolation technique by kriging as a method of estimation of unsampled locations without bias and minimum variance (Yu-Pin et al., 2010).

Soil tests provide information about the quantity of plant available nutrients in soil. Blanket nutrient application leads to over or under fertilization in cultivated areas causes severe yield losses by changing nutrient availability in soils. Soil heterogeneity is responsible for uneven adsorption, absorption, uptake of plant nutrients resulting nutrient deficiencies. Nutrient application to soil according to spatially variability provides the solution for blanket recommendation and to enhance fertilizer use efficiency. Hence this research work is designed with an objective to develop the thematic maps on spatial variability soil properties by using geostatistics and GIS techniques to enhance the vegetable production by means of site specific nutrient management.

\section{Materials and Methods}

The study area, western farm of HC\&RI is located in Endapuli village, Periyakulam taluk of Theni district of Tamil Nadu lies between from $10^{\circ} 7^{\prime} 19^{\prime \prime}$ to $10^{\circ} 7^{\prime} 50^{\prime \prime}$ North latitude and from $77^{\circ} 35^{\prime} 14 "$ to $77^{\circ} 35^{\prime} 28^{\prime \prime}$ of East Longitude is covered by SOI toposheet No. 58F12with total an area of50 ha. The elevation is $300 \mathrm{MSLwith}$ an average annual temperature range of 21 to $38{ }^{\circ} \mathrm{C}$ and average annual rainfall of $780 \mathrm{~mm}$. The major crops grown are tomato, moringa, bhendi, chilies, snake guard, bitter guard, vegetable cowpea, beetroot, brinjal, onion, green leafy vegetables and pumpkin. The geographical location of the study area and sampling points are given Fig. 1.

Three hundred and twenty soil samples were collected from entire farm at randomly distributed locations with coordinates of sampling site using GPS. The soil sample were analyzed for $\mathrm{pH}$, electrical conductivity (EC) organic carbon (OC), calcium carbonate $\left(\mathrm{CaCO}_{3}\right)$, available $\mathrm{N}, \mathrm{P}, \mathrm{K}, \mathrm{S}$ and micronutrients (Jackson,1973).The soil samples were categorized into low, medium and high categories based on the ratings of nutrients. The percentage deficiency of sample for each nutrient was assessed by comparing nutrient ratings. Nutrient index value (NIV) was calculated from the proportion of sample under low, medium and high available nutrient categories as represented by

$$
\mathrm{NIV}=\frac{\left[\left(\mathrm{P}_{\mathrm{H}}^{* 3}\right)+\left(\mathrm{P}_{\mathrm{M}} * 2\right)+\left(\mathrm{P}_{\mathrm{L}} * 1\right)\right]}{100}
$$

Where, $\mathrm{P}_{\mathrm{L}}, \mathrm{P}_{\mathrm{M}}$ and $\mathrm{P}_{\mathrm{H}}$ are percentage of soil samples falling under low, medium and high category of nutrient status and given weightage of one, two and three respectively. The index values are rated in to very high (>2.67), high (2.33-2.67), adequate (2.002.33), marginal (1.67-2.00), low (1.33-1.67) and very low $(<1.33)$ fertility groups (Ramamurthy and Bajaj, 1969)

Descriptive statistics including mean, standard deviation and regression were computed among the nutrient content with 
relevant physiochemical properties of soils. Co-efficient of variance (CV) was used to examine the variability of determined parameters. The parameters are categorized into least variable, moderately variable and highly variable based on $\mathrm{CV}$ values $<15 \%$, 15 to $35 \%$ and $>35 \%$ respectively (Ghulam Nabi et al., 2019). Digital nutrient maps were prepared using GPS coordinates in Arc-GIS software with Spatial Analyst by employing kriging as interpolation method and the maps were reclassified based on ratings of respective parameters.

\section{Results and Discussion}

The soil texture of western farm varied from sandy loam to sandy clay loam. Sand, silt and clay content of soils ranged from 71.6- 83.8, 3.0-10.0 and 10.8-22.4 per cent respectively with $\mathrm{CV}$ of 3,23 and $16 \%$ respectively (Table 1).

\section{Soil physico chemical properties}

Soil $\mathrm{pH}$ indicates the chemical nature of soil and varied from 6.78 to 8.67 with mean of7.77. According to $\mathrm{pH}$, majority of the soils were alkaline in nature, due to indigenous parent material, calcareousness and low organic matter content (Khalid et al., 2012). Soil organic matter is an essential component for soil health, includes a range of organic compounds and materials such as humic substances, carbohydrates, proteins and plant residues. Organic matter in soils ranged from 1.1 to $8.6 \mathrm{~g} \mathrm{~kg}^{-1}$ with mean of $2.9 \mathrm{~g} \mathrm{~kg}^{-1}$ and data revealed that 93, 6 and $1 \%$ of samples were poor, satisfactory and adequate range respectively. The buildup of organic matter in soils is mainly related to natural vegetation, cropping history and temperature (Patil et al., 2011).

Calcium carbonate is one of the factor for controlling soil $\mathrm{pH}$ and consequently limit the availability of nutrients in soils. The free $\mathrm{CaCO}_{3}$ content in soil samples are ranged 0.25 to $8.91 \%$ with mean and $\mathrm{CV}$ of 2.9and $52 \%$ respectively and majority of soils are in slightly calcareous. The EC of samples are harmless to critical in crop growth ( 0.1 to $0.98 \mathrm{dSm}^{-1}$ ) and low EC values might be due to proper management of soil and there by leaching of salts take place from surface to subsurface (Vijayakumar et al., 2011).

\section{Available nutrient status}

The available $\mathrm{N}, \mathrm{P}$ and $\mathrm{K}$ status of the soils ranged from 101- 512;8 -30 and 102-378 with a mean of 232, 15.2 and $215 \mathrm{~kg} \mathrm{ha}^{-1}$ respectively (Table 2). The low organic carbon content in soils might be due to low or lack of addition of residues and organic manures (Patil et al., 2011). Nitrogen is the most limiting nutrient in soils because easily lost through leaching and volatilization. The available nitrogen content in soils is dependent on temperature and rainfall apart from application of recommended dose of fertilizer to high yielding varieties (Fig. 2).

Phosphorus availability depends on soil $\mathrm{pH}$, in acid soils $\mathrm{P}$ is associated with $\mathrm{Fe}$ and $\mathrm{Al}$ compounds, whereas in soils with $\mathrm{pH}$ higher than 6.5, associated with $\mathrm{Ca}$ and $\mathrm{Mg}$ (Aurélien Roger et al., 2014). Calcium carbonate content of soils showed significant and negative correlation with available phosphorus $\left(\mathrm{r}=-0.108^{* *}\right), \mathrm{Fe}(\mathrm{r}=-0.164 * *)$ and $\mathrm{Mn}\left(\mathrm{r}=-0.13^{* *}\right)$ and its relationship with other nutrients was negative and nonsignificant (Table 3). The negative correlation of $\mathrm{CaCO}_{3}$ with phosphorus might leads to formation of insoluble calcium phosphates, thus reducing its availability (Minhas and Bora, 1982). Exchangeable $\mathrm{K}$ form is mostly readily available, but others are slowly available, which depends on clay mineralogy and physicochemical properties. The soil biogeochemical properties and processes 
control the release and/or fixation of different forms $\mathrm{K}$. The distribution of soil $\mathrm{K}$ forms is influenced by environmental factors such as soil parent materials, degree of soil weathering, topography and nutrient balance (Zörb et al., 2014).

The available $S$ content is ranged from 4.4 to 39.3 with mean of $12.5 \mathrm{mg} \mathrm{kg}^{-1}$. Renukadevi et al., (2002) revealed that amount of sulphur depend upon primary minerals and organic compounds present in soil. Higher percentage of samples under sufficient level (> $20 \mathrm{mg}$ $\mathrm{kg}^{-1}$ ) might be due to addition of sulphur through super phosphate. However, because of continuous drain of sulphur by high yielding varieties, multiple cropping systems and high sulphur requiring crops, without its replenishment, the deficiency of sulphur has started occurring in certain pockets.

The data revealed that $\mathrm{pH}$ of surface soils showed non-significant negative correlation with available nitrogen ( $\mathrm{r}=-0.041)$, phosphorus $(r=-0.087)$ and non-significant positive correlation with available potassium. Simultaneously, soil $\mathrm{pH}$ exhibited significant and positive correlation with free $\mathrm{CaCO}_{3}(\mathrm{r}=$ $\left.0.170^{* *}\right)$ and available sulphur $\left(\mathrm{r}=0.165^{* *}\right)$ and significant negative correlation with DTPA micronutrients. The negative correlation between soil $\mathrm{pH}$ and available nitrogen might be due to volatilization loss of nitrogen with rise $\mathrm{pH}$ of soil. The negative significant relationship between soil $\mathrm{pH}$ and available phosphorus might be due to conversion of soluble phosphorus to insoluble $\mathrm{Ca}$ and $\mathrm{Mg}$ phosphates, thus reducing its availability with increase in soil $\mathrm{pH}$. The increase in free $\mathrm{CaCO}_{3}$ with increase of soil $\mathrm{pH}$ is due to basic nature of Ca cation (Patil et al., 2011).

The soil organic carbon showed positive and significant correlation with available nitrogen $(\mathrm{r}=0.220)$, phosphorus $(\mathrm{r}=0.153)$, sulphur $(\mathrm{r}$ $=0.155)$, iron $(\mathrm{r}=0.251)$, zinc $(\mathrm{r}=0.157 * *)$, manganese $\left(\mathrm{r}=0.183^{* *}\right), \mathrm{Cu}\left(\mathrm{r}=0.166^{* *}\right)$ and HWSB $\left(\mathrm{r}=0.225^{* *}\right)$ while it was nonsignificant and positive correlation with potassium. The significant and positive correlation between organic carbon and available nitrogen could be because of release of mineralizable nitrogen from soil organic matter in proportionate amounts and adsorption of $\mathrm{NH}_{4}-\mathrm{N}$ by humus complexes in soil. The significant and positive correlation between organic carbon and available phosphorus might be due to acidulating effect of organic carbon, formation of easily accessible organophosphate complexes, release of phosphorus from organic complexes and reduction in phosphorus fixation by humus due to formation of coatings on iron and aluminum oxides. The increase in availability of sulphur by organic carbon might be attributed to release of sulphur from organic complexes as well as acidulating action of soil organic carbon thus enhancing the weathering of minerals containing sulphur (Singh et al., 2014).

The available iron content of soils ranged from 5.8 to 43.3 with mean of $15.9 \mathrm{mg} \mathrm{kg}^{-1}$. Nearly 17.5 and 82.5 per cent samples were grouped under medium (3.7-8.0 mg kg-1) and high ( $\left.>8 \mathrm{mg} \mathrm{kg}^{-1}\right)$ status. The problem related to iron deficiency is mainly due to its available pool rather than total content in soil. When soil $\mathrm{pH}$ exceeds 6.5 to 7.0 , iron availability is greatly reduced and at high $\mathrm{pH}$, iron might precipitate as insoluble $\mathrm{Fe}(\mathrm{OH})_{2}$. The presence of free $\mathrm{CaCO}_{3}$ might reduce the availability of iron due to precipitation or oxidation of $\mathrm{Fe}^{2+}$ toFe ${ }^{3+}$ oxides or precipitation as carbonates as obtained negative correlation between DTPA- Fe and free $\mathrm{CaCO}_{3}\left(\mathrm{r}=-0.251^{* *}\right)$ and DTPA- Fe and $\mathrm{pH}(\mathrm{r}=-0198 * *)$. The increase in DTPA-Fe content with increase in soil organic carbon is supported by overall positive correlation obtained between DTPA- Fe and organic carbon $\left(\mathrm{r}=0.251^{* *}\right)$ as reported by Murthy et al., (2005). 
The available manganese content was varied from 0.56 to 8.1 with a mean of $3.1 \mathrm{mg} \mathrm{kg}^{-1}$. The high status of manganese content in soils might be due to lower oxidation state of manganese are more soluble than higher oxidation state. The variation in manganese content might be due to variable intensity of different pedogenic process taking place during soil development. The decomposition of organic matter reduces the $\mathrm{pH}$ of soil locally which helps in increasing the solubility of cationic micronutrients as confirmed by correlation between organic carbon and DTPA-Mn $\left(\mathrm{r}=0.183^{* *}\right)$.The adsorption of manganese on the surface of calcium carbonate might have decreased the availability $\left(\mathrm{r}=-0.123^{*}\right)$. The decrease in soil $\mathrm{pH}$, increase the solubility of DTPA-Mn ( $\mathrm{r}=-$ $0.105^{*}$ ) while increase in organic matter, increases the exchange capacity and surface area of soil leading to more retention of DTPA- Mn, resulting increase availability of DTPA-Zn $\left(\mathrm{r}=0.183^{* *}\right)$

The DTPA-Zn varied from 0.18-3.63 with mean of $1.3 \mathrm{mg} \mathrm{kg}^{-1}$. Climatic conditions, parent materials and management practices are largely responsible for distribution of zinc in soil. Coarse texture, high $\mathrm{pH}$, calcareousness, diminishing organic carbon and leaching often accentuated the zinc deficiency.

The low availability of $\mathrm{Zn}$ content in soils might be due to low organic carbon content as confirmed by correlation between organic carbon and DTPA- Zn. The increase in DTPA-Zn with decrease in soil $\mathrm{pH}$ was substantiated by overall negative correlation obtained between DTPA- $\mathrm{Zn}$ and soil $\mathrm{pH}(\mathrm{r}=$ $\left.0.103^{*}\right)$ as narrated by Sidhu and Sharma (2010).

The available copper ranged from 0.10 to 1.94 with a mean of $0.53 \mathrm{mg} \mathrm{kg}^{-1}$. Natural concentration of $\mathrm{Cu}$ in soils depends primarily on the geochemistry of parent material and could exhibit high spatial variability over heterogeneous lithologies. Soil properties, such as $\mathrm{pH}$, organic matter content, cation exchange capacity, clay content and available $\mathrm{P}$ are influenced the soil $\mathrm{Cu}$. In western farm 98.4 per cent samples are deficient in available copper and deficiencies are mainly due to low organic matter content in soils. The availability decreases with increasing $\mathrm{pH}$ $\left(\mathrm{r}=-0.148^{* *}\right)$ might be due to precipitation of copper as its hydroxides. Newly formed hydroxides would have either become the part of lattice or occluded with hydroxides of $\mathrm{Fe}$, $\mathrm{Al}$ and $\mathrm{Mn}$.

The main factor affecting DTPA-Cu availability was found as the soil $\mathrm{pH}(\mathrm{r}=$ 0.166**) (Kumar and Babel, 2011).

The HWS-B in soils ranged from 0.11 to 3.6 with mean of $0.69 \mathrm{mg} \mathrm{kg}^{-1}$. The availability of boron is largely influenced by $\mathrm{pH}$, organic carbon, texture and calcium carbonate content. As per the critical limits of B, 43.1, 40.0 and 16.9 per cent samples were under low, medium and high category respectively. High levels of boron in soils might be due to naturally high concentration of boron in soils or continued use of irrigation water containing high in soluble salts of boron. The HWSB content increased with increase in organic carbon content of soil which is substantiated by an overall significant positive correlation of HWSB with organic carbon $(\mathrm{r}=$ $\left.0.225^{* *}\right)$.

The significant and positive correlation between soil organic carbon and available micronutrients might be due to formation of chelates by organic matter, release of micronutrients from organic complexes, acidulating action of soil organic carbon and decrease in soil $\mathrm{pH}$ thus increasing the solubility of complexes (Nazif et al., 2006). 
Per cent sample deficiency and nutrient index values

Per cent sample deficiency for available nutrients revealed that available $\mathrm{N}$ was most deficient $(91.3 \%)$ nutrient among the major nutrients (Table 4). For micronutrients, 15.9, $57.2,98.4$ and $43.1 \%$ of samples were comes deficient for available $\mathrm{Mn}, \mathrm{Zn}, \mathrm{Cu}$ and $\mathrm{B}$ as per the critical limits. None of the samples were deficient for DTPA Fe and 17.5 and $82.5 \%$ of samples were belongs to medium and high Fe status respectively. For available Sulphur, 25, 52.5 and $22.5 \%$ of samples were comes under low, medium and high status respectively.

Table.1 Physicochemical properties of soils in western farm of HC\&RI, Periyakulam

\begin{tabular}{|l|c|c|c|c|}
\hline Properties & Mean & Range & SD & CV \\
\hline $\mathrm{pH}$ & 7.77 & $6.8-8.7$ & 0.49 & 0.06 \\
\hline $\mathrm{EC}\left(\mathrm{d} \mathrm{Sm}^{-1}\right)$ & 0.24 & $0.1-1.0$ & 0.12 & 0.49 \\
\hline Organic carbon $\left(\mathrm{g} \mathrm{kg}^{-1}\right)$ & 2.9 & $1.1-8.6$ & 1.26 & 0.43 \\
\hline Free $\mathrm{CaCO}_{3}(\%)$ & 2.99 & $0.3-8.9$ & 1.56 & 0.52 \\
\hline Sand $(\%)$ & 76.6 & $71.6-83.8$ & 2.9 & 0.03 \\
\hline Silt $(\%)$ & 7.1 & $3.0-10.0$ & 1.6 & 0.23 \\
\hline Clay $(\%)$ & 16.5 & $10.6-22.4$ & 2.6 & 0.16 \\
\hline
\end{tabular}

Table.2 Range and mean values of various soil analytical parameters $(n=320)$

\begin{tabular}{|l|c|c|c|c|}
\hline Nutrients & Mean & Range & SD & CV \\
\hline Available N $\left(\mathrm{kg} \mathrm{ha}^{-1}\right)$ & 232 & $101-512$ & 49.9 & 0.21 \\
\hline Available $\mathrm{P}\left(\mathrm{kg} \mathrm{ha}^{-1}\right)$ & 15.2 & $7.9-29.5$ & 4.1 & 0.27 \\
\hline Available K $\left(\mathrm{kg} \mathrm{ha}^{-1}\right)$ & 215 & $102-378$ & 51.4 & 0.24 \\
\hline Available $\mathrm{S}\left(\mathrm{mg} \mathrm{kg}^{-1}\right)$ & 12.5 & $4.4-39.3$ & 3.9 & 0.31 \\
\hline DTPA- Fe $\left(\mathrm{mg} \mathrm{kg}^{-1}\right)$ & 15.9 & $5.8-43.3$ & 8.1 & 0.51 \\
\hline DTPA- $\mathrm{Mn}\left(\mathrm{mg} \mathrm{kg}^{-1}\right)$ & 3.1 & $0.56-8.1$ & 1.3 & 0.40 \\
\hline DTPA- Zn $\left(\mathrm{mg} \mathrm{kg}^{-1}\right)$ & 1.3 & $0.18-3.63$ & 0.7 & 0.55 \\
\hline DTPA- $\mathrm{Cu}\left(\mathrm{mg} \mathrm{kg}^{-1}\right)$ & 0.53 & $0.10-1.94$ & 0.3 & 0.48 \\
\hline HWS-B $\left(\mathrm{mg} \mathrm{kg}^{-1}\right)$ & 0.69 & $0.11-3.6$ & 0.5 & 0.74 \\
\hline
\end{tabular}

Table.3 Correlation coefficient (r) between physiochemical properties and soil available nutrients

\begin{tabular}{|c|c|c|c|c|c|c|c|c|c|}
\hline \multirow{2}{*}{$\begin{array}{l}\text { Physical } \\
\text { properties }\end{array}$} & \multicolumn{9}{|c|}{ Soil available nutrients } \\
\hline & $\mathrm{N}$ & $\mathrm{P}$ & $\mathrm{K}$ & $\mathrm{S}$ & $\mathrm{Fe}$ & $\mathrm{Mn}$ & $\mathrm{Zn}$ & $\mathrm{Cu}$ & $\mathrm{B}$ \\
\hline $\mathrm{pH}$ & -0.041 & -0.087 & 0.007 & $0.165^{* *}$ & $-0.198 * *$ & $-0.105^{*}$ & $-0.103 *$ & $-0.148 * *$ & $-0.117 *$ \\
\hline EC & 0.119 & -0.039 & 0.05 & 0.037 & -0.072 & 0.080 & 0.037 & -0.102 & $-0.215^{* *}$ \\
\hline OC & $0.22 * *$ & $0.153^{* *}$ & -0.082 & $0.155^{* *}$ & $0.251 * *$ & $0.183^{* *}$ & $0.157^{* *}$ & $0.166^{* * *}$ & $0.225 * *$ \\
\hline $\mathrm{CaCO}_{3}$ & 0.063 & $-0.108 * *$ & -0.072 & -0.019 & $-0.164 * *$ & $-0.123^{*}$ & -0.046 & -0.079 & -0.127 \\
\hline
\end{tabular}


Fig.1 The geographical location of the study area and soil sampling points

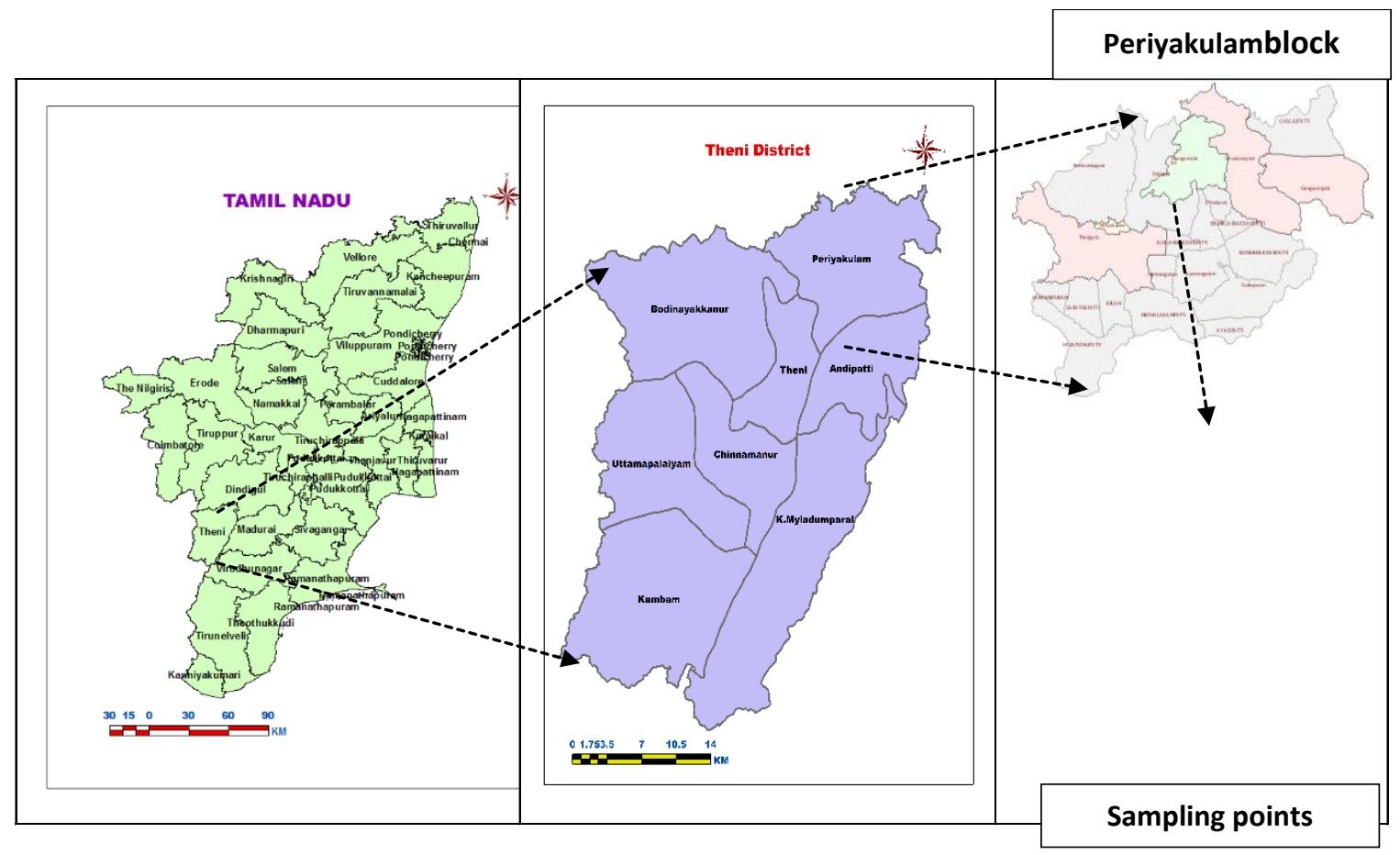

Fig.2 Spatial variability maps for soil $\mathrm{pH}$, available N, Zn, and B

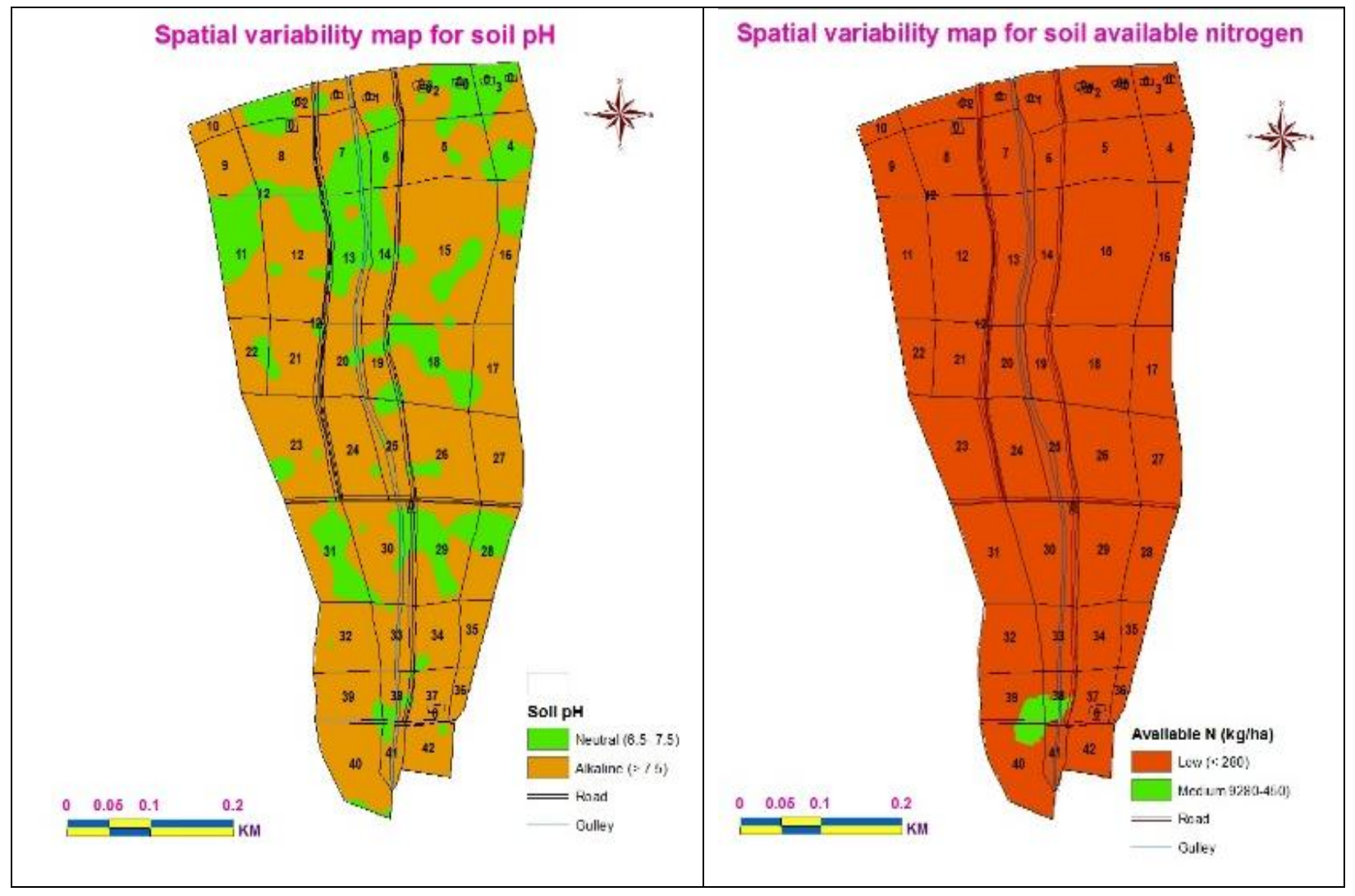




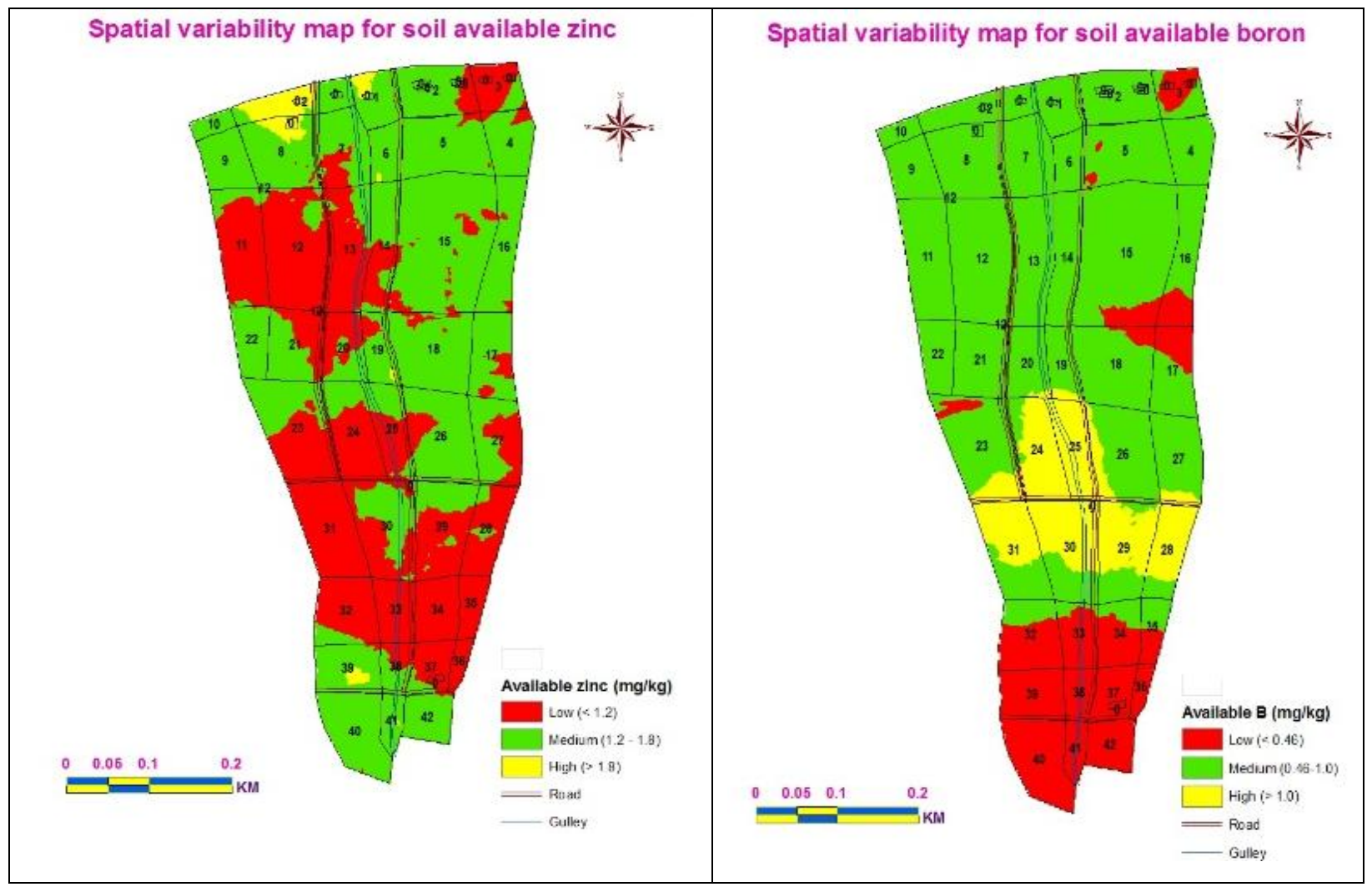

Table.4 Percentage deficiency, Nutrient index values and fertility status for available nutrients

\begin{tabular}{|c|c|c|c|}
\hline Nutrient & Per cent sample deficient & Nutrient index value & Fertility status \\
\hline $\mathrm{N}$ & 91.3 & 1.09 & Very low \\
\hline $\mathrm{P}$ & 15.3 & 1.88 & Marginal \\
\hline $\mathrm{K}$ & 1.6 & 2.07 & Adequate \\
\hline $\mathrm{S}$ & 25.0 & 1.98 & Marginal \\
\hline $\mathrm{Fe}$ & 0.0 & 2.83 & Very high \\
\hline $\mathrm{Mn}$ & 15.9 & 2.01 & Adequate \\
\hline $\mathrm{Zn}$ & 57.2 & 1.61 & Low \\
\hline $\mathrm{Cu}$ & 98.4 & 1.02 & Very low \\
\hline $\mathrm{B}$ & 43.1 & 1.74 & Marginal \\
\hline
\end{tabular}

Among the major nutrients, nitrogen registered the lowest nutrient index value of 1.09 followed by phosphorus (1.88) and potassium (2.07). For micronutrients the order of nutrient index value was $\mathrm{Fe}>\mathrm{Mn}>\mathrm{Zn}>\mathrm{B}$ $>\mathrm{Cu}$. The index value for available $\mathrm{Fe}, \mathrm{Mn}$, $\mathrm{Zn}, \mathrm{B}$ and $\mathrm{Cu}$ was $2.83,2.01,1.61,1.74$ and 1.02 respectively. The nutrient index value for available sulphur is 1.98.As per the nutrient index value, fertility class of the western farm of HC\&RI soil samples are very low, marginal and adequate respectively for available $\mathrm{N}, \mathrm{P}$ and $\mathrm{K}$. With regard to micronutrients, the fertility classes are very high, adequate, low, very low and marginal for DTPA extractable $\mathrm{Fe}, \mathrm{Mn}, \mathrm{Zn} \mathrm{Cu}$ and HWSB respectively. The fertility class for available sulphur is marginal in status. 
For depict the intensity of available nutrients and physico chemical properties, the spatial variability (thematic) maps were prepared separately for every analysed parameters. Using ArcGIS software, Inverse distance weighted model was fitted to semivarogram in order to create continuous surface for estimated soil properties. The thematic maps on physico chemical properties $(\mathrm{pH}, \mathrm{EC}$, Free $\left.\mathrm{CaCO}_{3}\right)$ and available nutrient status $(\mathrm{N}, \mathrm{P}$, $\mathrm{K}, \mathrm{S}, \mathrm{Fe}, \mathrm{Mn}, \mathrm{Zn}, \mathrm{Cu}, \mathrm{B})$ were generated by categorizing the fertility status as low, medium and high by showing in colour difference on the maps.

From the study, it is concluded that deficiencies of available $\mathrm{N}$ and DTPA-Cu are most common in western farm soils and caused decline in crop yields and total productivity. Soil factors such as $\mathrm{pH}$, organic carbon are main factors for contributing variability and availability of nutrients. Strategies involving the application of nitrogen and micronutrients especially $\mathrm{Cu}, \mathrm{Zn}$ and B as soil and foliar sprays or use of organic manures can be adopted to sustain optimum yield potential. Generated maps could be a guide for scientist and researchers to conduct field trials in delineated areas and nutrient application for site specific nutrient management practices that would help in improving fertilizer use efficiency, reducing cost of cultivation and preventing environmental pollution.

\section{References}

Aurélien Roger, ZamirLibohova, Nicolas Rossier, Stéphane Joost, Alexandra Maltas, Emmanuel Frossard and Sokrat Sinaj. 2014. Spatial variability of soil phosphorus in the Fribourg canton, Switzerland. Geoderma.217-218: 2636.

Ghulam Nabi, Humair Ahmed, Ijaz Ali and
Shahid Maqsood Gill. 2019. Spatial variability and digital mapping of $\mathrm{Zn}$ content in soil and foliage of wheat producing area in district JhelumPakistan. International Journal of Biosciences. 14: 72-81.

Jackson, M.L. 1973. Soil Chemical Analysis. Prentice Hall of India, New Delhi.

Khalid, R., Mahmood, T., Bibi, R., Siddique, M.T., Alvi, S. and Naz, S.Y.2012. Distribution and indexation of plant available nutrients of rainfed calcareous soils of Pakistan. Soil and Environment.31: 146-151.

Kumar, M. and Babel, A.L. 2011. Available micronutrient status and their relationship with soil properties of Jhunjhunu Tehsil district Jhunjhunu, Rajasthan, India. Journal of Agricultural Sciences. 3: 97-106.

Minhas, R.S. and Bora, N.C. 1982. Distribution of organic carbon and the forms of nitrogen in topopgroiphic sequence of soil. Journal of the Indian society of Soil science.30:135-139.

Murthy, K.R. and Srinivas, M.C.A. 2005. Distribution of some available micronutrients in black and red soils of Karnataka. Mysore Journal of agricultural Sciences.39: 57-63.

Nazif, W., Perveen, S. and Saleem, I. 2006. Status of micronutrients in soils of district Bhimber (Azad Jammu and Kashmir). Journal of Agriculture and Biological Sciences. 1: 35-40.

Patil, S.S., Patil, V.C. and Al-Gaadi, K.A. 2011.Spatial Variability in Fertility Status of Surface Soils. World Applied Science Journal.14: 1020-1024.

Ramamurthy, B. and Bajaj, J.C. 1969. Available nitrogen, phosphorus and potassium status of Indian soils. Fertilizer News. 14: 25-36.

Renukadevi, A., Radhakrishnan, G., Jagadeeswari, P.V. and Lakkawar, V.W. 2002. Sulphur in soil-An overview. In: 
National seminar on recent trends in Sulphur and Silicon nutrition of crops, held at Madurai on June 12-13.

Sidhu,G.S. and Sharma, B.D. 2010. Diethylene triamine penta acetic acid extractable micronutrients status in soil under a rice - wheat system and their relationship with soil properties in different agro-climatic zones of IndoGangetic Plains of India. Communications in Soil Science and Plant Analysis.41:29-51.

Singh, S., Bhat, Z.A. and Rehman H.U. 2014. Influence of organic and integrated nutrient management on physicochemical properties of soil under basmati-wheat sequence. The Bioscan.9: 1471-1478.

Sood, A., Sharma, P.K. Tur, N.S. and Nayyar, V.K. (2009) Micronutrient status and their spatial variability in soils of Muktsar District of Punjab- A GIS approach. Journal of the Indian society of Soil science.57 (3): 300-306.

Vijayakumar, R., Arokiaraj, A. and Martin Deva Prasad, P. (2011) Micronutrients Status and Their Relation to Soil Characteristics of South- East Coastal Soils of India. International Journal of Research Chemical Environment.1: 147-150.

Yu-Pin, L., Bai-You, C., Guey-Shin, S., and Tsun-Kuo, C. (2010). Combination a finite mixture distribution model with indicator kriging to delineated and map the spatial patterns of soil heavy metal pollution in Chunghua Country, central Taiwan. Environmental Pollution.158: 235-244.

Zörb, C., Senbayram, M. and Peiter, E. (2014) Potassium in agriculture status and perspectives. Journal of Plant Physiology.171:656-669.

\section{How to cite this article:}

Muthumanickam, D. 2020. Spatial Variability Mapping of Available Nutrient Status in Vegetable Grown Soils Using GIS Techniques. Int.J.Curr.Microbiol.App.Sci. 9(05): 32273236. doi: https://doi.org/10.20546/ijcmas.2020.905.383 